\title{
Arsenic(III) Remediation from Contaminated Water by Oxidation and Fe/Al Co-Precipitation
}

\author{
Wensheng Zhang ${ }^{1}$, Pritam Singh ${ }^{2}$, Touma B. Issa ${ }^{2}$ \\ ${ }^{1}$ CSIRO Process Science and Engineering, CSIRO, Bentley, Karawara, Australia \\ ${ }^{2}$ School of Chemical and Mathematical Sciences, Murdoch University, Murdoch, Australia \\ E-mail: wensheng.zhang@csiro.au, \{P.Singh,T.Issa $\} @ m u r d o c h . e d u . a u$ \\ Received March 14, 2011; revised June 15, 2011; accepted August 17, 2011
}

\begin{abstract}
Battery grade $\gamma-\mathrm{MnO}_{2}$ powder was investigated as an oxidant and an adsorbent in combination with $\mathrm{Fe} / \mathrm{Al}$ coagulants for removal of arsenic from contaminated water. Simultaneous oxidation of As(III) and removal by coprecipitation/adsorption (one step process) was compared with pre-oxidation and subsequent removal by coprecipitation/adsorption (two step process). The rate of $\mathrm{As}(\mathrm{III})$ oxidation with $\mathrm{MnO}_{2}$ is completed in two stages: rapid initially followed by a first order reaction. $\mathrm{As}(\mathrm{III})$ is oxidised to $\mathrm{As}(\mathrm{V})$ by the $\mathrm{MnO}_{2}$ with a release of approximately 1:1 molar $\mathrm{Mn}(\mathrm{II})$ into the solution. No significant $\mathrm{pH}$ effect on oxidation of As(III) was observed in the $\mathrm{pH}$ range $4-6$. The rate showed a decreasing trend above $\mathrm{pH}$ 6. The removal of As(V) by adsorption on the $\mathrm{MnO}_{2}$ decreased significantly with increasing $\mathrm{pH}$ from 4 to 8 . The adsorption capacity of the $\gamma-\mathrm{MnO}_{2}$ with particle size $90 \%$ passing $10 \mu \mathrm{m}$ was determined to be $1.5 \mathrm{mg} / \mathrm{g}$ at $\mathrm{pH} 7 . \mathrm{MnO}_{2}$ was found to be more effective as an oxidant for As(III) in the two step process than in the one step process.
\end{abstract}

Keywords: Manganese Oxides, Iron Hydroxides, Arsenic Remediation, Fe/Al Coagulants, Contaminated Water

\section{Introduction}

Arsenic in contaminated groundwater occurs largely as arsenite (As(III)). [1] Effective and complete removal of arsenic by adsorption/coprecipitation methods requires pre-oxidation of $\mathrm{As}(\mathrm{III})$ to $\mathrm{As}(\mathrm{V})$. Oxygen or air is a cheap but kinetically slow oxidant for As(III). Various other oxidants for As(III) have been reported in the literature, including permanganate $\left(\mathrm{MnO}_{4}^{-}\right),[2-4]$ ozone (O3), [5] hydrogen peroxide $\left(\mathrm{H}_{2} \mathrm{O}_{2}\right)$, [6] chlorine $\left(\mathrm{Cl}_{2}\right)$, [7-10] or hypochlorite $\left(\mathrm{ClO}^{-}\right)$, [11-13] catalyzed sulphite $/ \mathrm{O}_{2}$ (air) mixture, $[14,15]$ and UV catalyzed systems. [16-19] These oxidants are effective but are either costly, or need rigid process controls for efficient oxidation. In recent years, manganese oxides, in both synthetic and natural forms, have been investigated for oxidation of As(III) [20-26].

Oscarson et al. [27] found that the oxidation of As(III) by birnessite, cryptomelane, and pyrolusite obeyed the first-order rate law with the rate constants at $298 \mathrm{~K}$ being $0.267,0.189$ and $0.44 \times 10^{-3} \mathrm{~h}^{-1}$, respectively. However, Chen and Fang [28] reported that the oxidation rate of As(III) by $\mathrm{MnO}_{2}$ was rapid initially followed by a first- order kinetics with respect to As(III) concentration. The activation energies for the oxidation reaction by the $\mathrm{MnO}_{2}$ were measured to be in the range $26.0-32.3$ $\mathrm{kJ} / \mathrm{mol}$ [27]. The oxidation process was reported to be limited by diffusion of the reactant As(III) to or the reaction products away from the surface [27-29].

Scott and Morgan [29] proposed a surface mechanism that $\mathrm{As}(\mathrm{III})$ anion forms an inner-sphere complex followed by electron transfer between the surface metal ion and As(III) anion. The adsorption of As(III) on the surface was the slowest step. The surface mechanism was supported by the observation that the rate of As(III) oxidation directly depended on the concentration of surfacebound As(III) [30]. A mechanism of production of an intermediate reaction product, $\mathrm{Mn}(\mathrm{III})$ hydroxyl $\left(\mathrm{MnOOH}^{*}\right)$, was proposed by Nesbitt et al. [31].

$$
\begin{gathered}
2 \mathrm{MnO}_{2}+\mathrm{H}_{3} \mathrm{AsO}_{3}=2 \mathrm{MnOOH}^{*}+\mathrm{H}_{3} \mathrm{AsO}_{4} \\
2 \mathrm{MnOOH}^{*}+\mathrm{H}_{3} \mathrm{AsO}_{3}=2 \mathrm{MnO}+\mathrm{H}_{3} \mathrm{AsO}_{4}+\mathrm{H}_{2} \mathrm{O}
\end{gathered}
$$

Various forms of Mn oxides as adsorbent for arsenic removal have also been investigated, including pyrolusite and cryptomelane, [32] combination of pyrolusite with granular ferric hydroxide, [30] natural manganese oxides 
in a packed bed or column, [33] ferruginous manganese ore (FMO), [34] Mn dioxide-coated sand (MDCS), [35, 36] and Bi-enhanced Mn oxides [37]. Chiu and Hering [30] compared the adsorption capacities for different types of Mn oxides. They found that the surface saturation for pyrolusite and cryptomelane at $\mathrm{pH} 6.5$ for $\mathrm{As}(\mathrm{V})$ species were 0.75 and $1.87 \mathrm{mg} / \mathrm{g}$, respectively. The difference in the adsorption capacity was attributed to their crystallinity and specific surface areas. Poorly crystalline birnessite and cryptomelane possess higher specific surface areas than highly ordered pyrolusite [29].

This paper reports the investigation of $\mathrm{MnO}_{2}$ as an oxidant for As(III) and as adsorbent in combination with $\mathrm{Fe} / \mathrm{Al}$ coagulants for $\mathrm{As}(\mathrm{V})$ removal. The adsorption capacity of $\mathrm{MnO}_{2}$ for $\mathrm{As}(\mathrm{V})$ was compared with commonly used iron and aluminium hydroxide adsorbents under similar experimental conditions. Simultaneous oxidation and coprecipitation/adsorption (one step process), and pre-oxidation followed by coprecipitation/adsorption (two step processes) were investigated for various combinations of $\mathrm{MnO}_{2}$ with in-situ formed $\mathrm{Fe} / \mathrm{Al}$ hydroxides. The objectives of this work were to determine the suitability of $\mathrm{MnO}_{2}$ as an oxidant and adsorbent in combination with $\mathrm{Fe} / \mathrm{Al}$ hydroxide for arsenic removal.

\section{Materials and Methods}

First, Battery grade $\gamma-\mathrm{MnO}_{2}$ powder with particle size $90 \%$ passing $10 \mu \mathrm{m}$, supplied by Aldrich Australia, was used for all the experiments. All the other chemicals used were of AR grade without further treatment. As(III) stock solution was prepared from As2 33 in accordance with the procedure provided by Vogel [38]. As $(\mathrm{V})$ stock solution was prepared by dissolving $\mathrm{Na}_{2} \mathrm{HAsO}_{4}$ in demonized water. $\mathrm{Fe}(\mathrm{III})$ and $\mathrm{Al}(\mathrm{III})$ stock solutions were prepared from their chloride salts. Solution $\mathrm{pH}$ was adjusted with dilute $\mathrm{HCl}$ and $\mathrm{NaOH}$ solutions.

All the experiments were conducted at $25^{\circ} \mathrm{C}$ in $250 \mathrm{ml}$ conical flasks equipped with magnetic stirring units for liquid-solid mixing. In the one step process, a dose of $\mathrm{MnO}_{2}$ and a desired volume of equal molar $\mathrm{Fe}(\mathrm{III}) / \mathrm{Al}(\mathrm{III})$ solution were simultaneously added to water containing known amount of As(III) or As(V). Solution pH was adjusted and maintained at the desired value throughout the experiment. Samples were taken and filtered through a $0.2 \mu \mathrm{m}$ membrane filter. The filtrate was analysed for $\mathrm{As}(\mathrm{III})$ and $\mathrm{As}(\mathrm{V})$ by hydride generation followed by inductively coupled plasma and atomic emission spectroscopy (ICP-AES), and for total soluble Mn by ICPAES at the Marine and Freshwater Research Institute, Environmental Science, Murdoch University, Western Australia. For the two step process, the arsenic bearing solution was first treated with $\mathrm{MnO}_{2}$ followed by adsorption/precipitation with $\mathrm{Fe}(\mathrm{III}) / \mathrm{Al}(\mathrm{III})$ coagulants at $\mathrm{pH} 7$. All the other procedures were the same as the one step process.

\section{Results and Discussion}

\subsection{Oxidation of Arsenic(III) by $\mathrm{MnO}_{2}$}

\subsubsection{Stoichiometry of Oxidation of As(III)}

The stoichiometry of oxidation of As(III) by $\mathrm{MnO}_{2}$ was determined by measuring residual reactants and reaction products after 2 hours contact of one gram of the $\mathrm{MnO}_{2}$ powder with initial $1 \mathrm{ppm} \mathrm{As(III)} \mathrm{solution} \mathrm{at} \mathrm{pH} 7$ in the absence of oxygen maintained by bubbling nitrogen gas through the solution. The analysis results for residual concentrations of $\mathrm{As}(\mathrm{III}), \mathrm{As}(\mathrm{V})$ and $\mathrm{Mn}(\mathrm{II})$ in the final solution are given in Table 1. The important observations are:

No As(III) remained in the solution, indicating that all the As(III) was oxidized to $\mathrm{As}(\mathrm{V})$.

The residual arsenic in the solution accounted for only $80 \%$ of the amount initially present in the reaction mixture.

The solid phase contained the remaining $20 \%$ of the arsenic which could be assumed to be $\mathrm{As}(\mathrm{V})$.

The solution contained $\mathrm{Mn}(\mathrm{II})$ as much as would be expected if all the reacted $\mathrm{MnO}_{2}$ were converted to $\mathrm{Mn}$ (II) during its reaction with As(III). Thus, the oxidation of As(III) was accompanied by a reduction of $\mathrm{MnO}_{2}$ yielding $\mathrm{Mn}$ (II) into solution at an approximately equal molar stoichiometry with respect to the total oxidized As(III):

$$
\mathrm{Mn}(\mathrm{IV})+\mathrm{As}(\mathrm{III})=\mathrm{Mn}(\mathrm{II})+\mathrm{As}(\mathrm{V})
$$

\subsubsection{Rate of Oxidation of As(III)}

The rate of As(III) oxidation are plotted in Figure 1 and analyzed with respect to the first order rate law:

$$
\operatorname{Ln}[\operatorname{As}(\mathrm{III})] /[\mathrm{As}(\mathrm{III})]=\mathrm{kt}
$$

where $[\mathrm{As}(\mathrm{III})]$ is the initial As(III) concentration $(\mathrm{mg} / \mathrm{L})$, [As(III)] the concentration at time $\mathrm{t}(\mathrm{min}), \mathrm{k}$ the rate constant $\left(\mathrm{min}^{-1}\right)$ which is a function of $\mathrm{MnO}_{2}$ dose and tem-

Table 1. Concentrations of reaction products in the final solutions after 2 hour contact time at pH 7 and $25^{\circ} \mathrm{C}$. Initial 1 ppm As(III), 1 g/L $\mathrm{MnO}_{2}$.

\begin{tabular}{cccc}
\hline Elements & In solution $(\mu \mathrm{M})$ & In solid $(\mu \mathrm{M})$ & Total $(\mu \mathrm{M})$ \\
\hline $\mathrm{As}(\mathrm{III})$ & $<0.05(\mathrm{DL})$ & - & - \\
$\mathrm{As}(\mathrm{V})$ & 10.7 & 2.7 & 13.4 \\
$\mathrm{Mn}(\mathrm{II})$ & 14.0 & - & 14.0 \\
& Reaction product ratio As:Mn $\cong 1$ & \\
\hline
\end{tabular}


perature. As can be seen in Figure 1, the oxidation of As(III) by $\mathrm{MnO}_{2}$ could be characterized by very fast kinetics within the first 30 minutes, followed by a first order rate which is indicated by the fact that $\operatorname{Ln}[\mathrm{As}(\mathrm{III})] /$ $[\mathrm{As}(\mathrm{III})]$ vs reaction time $t$ is graphically linear. The rate increases with $\mathrm{MnO}_{2}$ dose, suggesting that the reaction depends on surface area or available reaction sites on the surface of $\mathrm{MnO}_{2}$. This two stage kinetic feature was also observed by Chen and Fang [28]. The slow-down in the rate at later stage of the reaction is indicative of competition for active adsorption sites between As(III) and $\mathrm{As}(\mathrm{V})$.

\subsubsection{Effect of $\mathbf{p H}$ on Oxidation of As(III)}

The $\mathrm{pH}$ effect was investigated by varying solution $\mathrm{pH}$ in the range $4-8$ and measuring the residual As(III) in solution after 2 hour contact time for each fixed $\mathrm{pH}$. The initial As(III) concentration was $6 \mathrm{mg} / \mathrm{L}$. It was observed that about $80 \%$ of the As(III) ions was oxidized for each $\mathrm{pH}$ in two hours in the $\mathrm{pH}$ range $4-6$. Above $\mathrm{pH} 6$, a decreased trend occurred up to $\mathrm{pH} 8$. This is likely to be caused by formation of manganese hydroxide on the surface which blocks some sites for reaction with As(III) on the surface.

\section{2. $\mathrm{MnO}_{2}$ as Adsorbent}

\subsubsection{Effect of $\mathbf{p H}$ on $\mathrm{As}(\mathrm{V})$ adsorption on $\mathrm{MnO}_{2}$}

Figure 2 shows that the $\% \mathrm{As}(\mathrm{V})$ adsorption decreases linearly when solution $\mathrm{pH}$ increases from $\mathrm{pH} 4$ to $\mathrm{pH} 8$. This effect can be explained by the surface charge characteristics of the $\mathrm{MnO}_{2}$ phase. The point of zero charge (PZC) of chemically or electrochemically prepared $\mathrm{MnO}_{2}$ materials such as $\alpha-\mathrm{MnO}_{2}, \gamma-\mathrm{MnO}_{2}$ and $\delta-\mathrm{MnO}_{2}$ lies in the $\mathrm{pH}$ range $1.5-4.15[39,40]$. Therefore, it is not surprising to observe the decreasing effect because the adsorption of $\mathrm{As}(\mathrm{V})$ species must overcome the increased

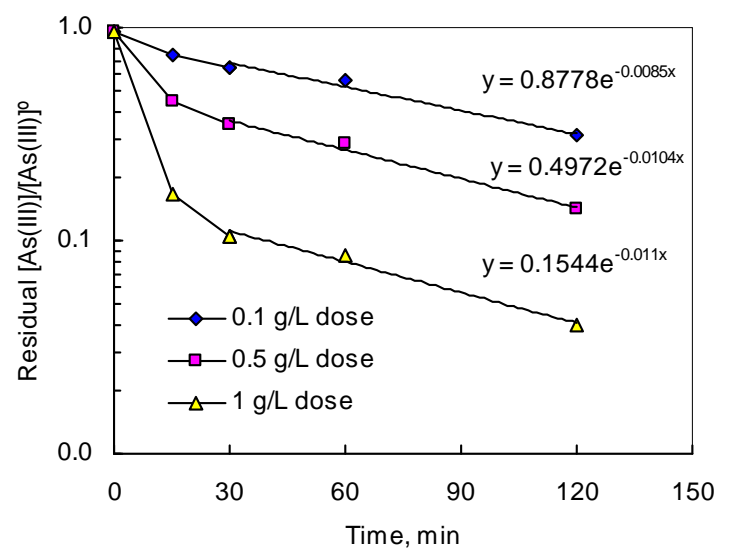

Figure 1. Ln $[\mathrm{As}(\mathrm{III})] /[\mathrm{As}(\mathrm{III})]^{\circ}$ vs time. Initial $5 \mathrm{mg} / \mathrm{L}$ As(III), pH 7, $25^{\circ} \mathrm{C}$.

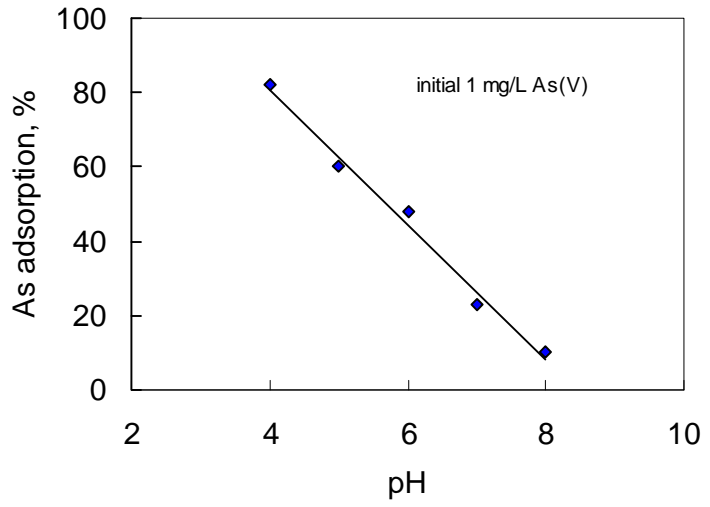

Figure 2. Effect of solution pH on adsorption of $\mathrm{As}(\mathrm{V})$ on the $\mathrm{MnO}_{2}$.

repulsion force as $\mathrm{pH}$ rose above the PZC. Additionally, the proportion of the more negatively charged $\mathrm{As}(\mathrm{V})$ species increases as the solution $\mathrm{pH}$ increases, e.g. $\mathrm{H}_{2} \mathrm{AsO}_{4}^{-}$ ions dominate in $\mathrm{pH}$ range $2-6.5$. The $\mathrm{H}_{2} \mathrm{AsO}_{4}^{2-}$ ions on the other hand dominate in $\mathrm{pH}$ range $6.5-11.8$. This should also contribute to the observed $\mathrm{pH}$ effect.

\subsubsection{Effect of $\operatorname{As}(\mathrm{V})$ Concentration}

The effect of $\mathrm{As}(\mathrm{V})$ concentration on $\mathrm{As}(\mathrm{V})$ adsorption was investigated by varying initial $\mathrm{As}(\mathrm{V})$ concentration at a fixed dose of $1 \mathrm{~g} / \mathrm{L} \mathrm{MnO}{ }_{2}$ at $\mathrm{pH}$ 7. As shown in Figure 3 , the results reasonably fit the Langmuir isotherm model:

$$
\mathrm{Ce} / \mathrm{Qe}=1 / \mathrm{bQ}^{\circ}+\mathrm{Ce} / \mathrm{Q}
$$

where, $\mathrm{Ce}(\mathrm{mmol} / \mathrm{L})$ is the equilibrium concentration in the solution, Qe $(\mathrm{mmol} / \mathrm{g})$ is the amount adsorbed on the adsorbent at equilibrium, $\mathrm{Q}^{\circ}$ and $\mathrm{b}$ are the Langmuir constants related to adsorption capacity and binding energy of adsorption respectively. From the slope of best fit, the adsorption capacity of the $\gamma-\mathrm{MnO}_{2}$ is determined to be $1.5 \mathrm{mg} / \mathrm{g}$.

For comparison, the adsorption capacities of commonly used iron and aluminum hydroxide adsorbents were also similarly studied and the reagents summarized in Table 2. The published data from the literature are also included in the table. As seen, the adsorption capacity of $\mathrm{MnO}_{2}$ increased in the order $\beta-\mathrm{MnO}_{2}<\gamma-\mathrm{MnO}_{2}<$ $\alpha-\mathrm{MnO}_{2}<<\delta-\mathrm{MnO}_{2}$. Clearly, the capacity depended on the form of $\mathrm{MnO}_{2}$ and its preparation method which determine the crystalline properties and surface area. For example, the amorphous $\delta-\mathrm{MnO}_{2}$ possesses highest surface area and thus highest adsorption capacity compared with other well crystalline forms of $\mathrm{MnO}_{2}$. However, the capacity of the amorphous $\delta-\mathrm{MnO}_{2}$ is found to be significantly lower than the amorphous iron hydroxide (ferrihydrite). The capacity of $\mathrm{As}(\mathrm{V})$ removal also depends on the method used. The removal of $\mathrm{As}(\mathrm{V})$ by adsorp- 
Table 2. Comparison of adsorption capacity of Mn oxides with iron oxides.

\begin{tabular}{|c|c|c|c|c|}
\hline & Hydroxides/oxides & Capacity (mg/g) & $\mathrm{pH}$ & Ref \\
\hline \multirow{3}{*}{ Mn Hydroxides/oxides } & Cryptomelane $\left(\alpha-\mathrm{MnO}_{2}\right)$ & 1.87 & 6.5 & {$[41]$} \\
\hline & $\gamma-\mathrm{MnO}_{2}$ & 1.5 & 7 & This work \\
\hline & Hydrous Mn(IV) oxide (HMO) or $\delta-\mathrm{MnO}_{2}$ & 5.5 & 6.5 & {$[41]$} \\
\hline \multirow{3}{*}{ Fe Hydroxides/oxides } & Preformed Ferrihydrite & 8.2 & 7 & This work \\
\hline & $\mathrm{Fe}(\mathrm{III})$ coagulant in-situ & 20 (on dry basis) & 7 & This work \\
\hline & $\mathrm{Fe}(\mathrm{III}) / \mathrm{Al}(\mathrm{III})$ coagulant in-situ & 30 (on dry basis) & 7 & This work \\
\hline
\end{tabular}

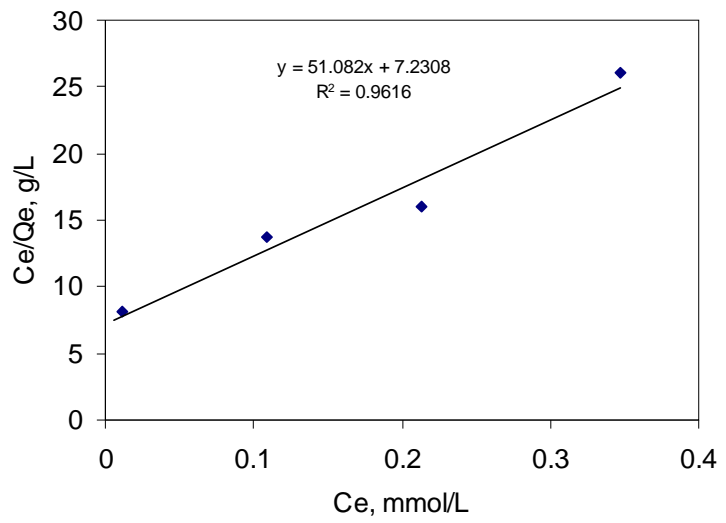

Figure 3. Langmuir plot for adsorption of $\mathrm{As}(\mathrm{V})$ on the $\mathrm{MnO}_{2}$ at $\mathrm{pH} 7$.

tion/precipitation in-situ with $\mathrm{Fe}(\mathrm{III})$ or $\mathrm{Fe}(\mathrm{III}) / \mathrm{Al}(\mathrm{III})$ coagulants is much more effective and efficient than the preformed ferrihydrite (Table 2).

\subsection{Removal of As(III) by $\mathrm{MnO}_{2}$ and $\mathrm{Fe}(\mathrm{III}) / \mathrm{Al}$ (III) Coagulants}

The efficiency of As(III) removal by adsorption on Fe/Al hydroxides was investigated in two ways:

One step process: this involved simultaneous addition of $\mathrm{MnO}_{2}$ oxidant and the $\mathrm{Fe}$ or $\mathrm{Fe} / \mathrm{Al}$ coagulant followed by $\mathrm{pH}$ adjustment.

Two step process: this involved pre-oxidation of As(III) by $\mathrm{MnO}_{2}$ and subsequent removal of $\mathrm{As}(\mathrm{V})$ by coprecipitation/adsorption on in-situ formed Fe or Fe/Al hydroxides.

- One step process

As shown in Figure 4, the residual arsenic in solution decreased exponentially from $0.2 \mathrm{mg} / \mathrm{L}$ to $0.02 \mathrm{mg} / \mathrm{L}$ as the $\mathrm{MnO}_{2}$ dose increased from $0.1 \mathrm{~g} / \mathrm{L}$ to $0.5 \mathrm{~g} / \mathrm{L}$. A dose of $1 \mathrm{~g} / \mathrm{L}$ of $\mathrm{MnO}_{2}$ was needed to lower the residual arsenic to $0.01 \mathrm{mg} / \mathrm{L}$ (standard drinking water limit by US Environmental Protection Agency). This reflects the relative inefficiency of the one step process for removal

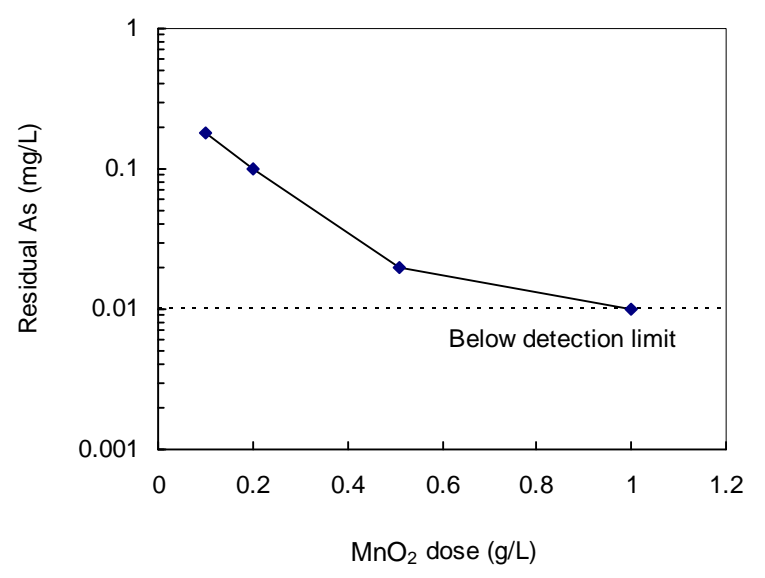

Figure 4. Effect of $\mathrm{MnO}_{2}$ dose on removal of arsenic by coprecipitation with Fe/Al coagulant. Initial $1 \mathrm{mg} / \mathrm{L} \mathrm{As(III),}$ pH 7, molar ratio (Fe:Al = 1:1):As = 50:1.

of very low level of arsenic.

- Two step processes

The results can be summarized as follows:

$\mathrm{Fe} / \mathrm{Al}$ alone is an effective adsorbent for $\mathrm{As}(\mathrm{V})(<0.01$ $\mathrm{mg} / \mathrm{L}$, Expt. Code 5) but poor for As(III) $(0.24 \mathrm{mg} / \mathrm{L}$, Expt. Code 4).

$\mathrm{MnO}_{2}$ alone is effective for As(III) oxidation (Expt. Code 6) but relatively poor adsorbent for As(V) (Expt. Code 7) compared with $\mathrm{Fe} / \mathrm{Al}$ adsorbent.

Combination of $\mathrm{MnO}_{2}$ with $\mathrm{Fe} / \mathrm{Al}$ in the one step process with initial As(III) effectively lowered the residual As to $0.01-0.02 \mathrm{mg} / \mathrm{L}$ (Expt. Code 2).

The two step process is more effective for arsenic removal $(<0.01 \mathrm{mg} / \mathrm{L}$ residual As, Expt. Code 1) than the one step process $(0.01-0.02 \mathrm{mg} / \mathrm{L}$ residual As, Expt. Code 2), but requires additional 2 hours for pre-oxidation.

Soluble Mn(II) was effectively removed from the system in both one-step and two-step processes.

The arsenic removal is not affected when $\mathrm{MnO}_{2}, \mathrm{Fe} / \mathrm{Al}$, and $\mathrm{As}(\mathrm{V})$ are co-present in the one step process (Expt. Code 3). 
The As(III) removal by the one step process is relatively poor compared with the two step process. Two factors are likely to affect the removal process. First, the in-situ formed amorphous $\mathrm{Fe} / \mathrm{Al}$ 'hydroxide' may partially cover the surface of $\mathrm{MnO}_{2}$, which slows down the diffusion process of As(III) to its surface. Second, the As(III) initially adsorbed on the surface of Fe/Al "hydroxide" is desorbed by $\mathrm{As}(\mathrm{V})$ ions, establishing a new equilibrium. As(III), which is known to occur as unionised $\mathrm{H}_{3} \mathrm{AsO}_{3}$ in the $\mathrm{pH}$ range $2-9$ is weakly bonded on the surface of ferrihydrite compared with $\mathrm{As}(\mathrm{V})$ which occur as $\mathrm{H}_{2} \mathrm{AsO}_{4}^{-}, \mathrm{H}_{2} \mathrm{AsO}_{4}^{2-}$. The $\mathrm{As}(\mathrm{V})$ species is strongly bonded on the surface via specific inner sphere adsorption mechanism. Furthermore, the As(III) adsorbed on the surface of ferrihydrite may need further treatment to oxidize the $\mathrm{As}(\mathrm{III})$ to $\mathrm{As}(\mathrm{V})$ for safe disposal. The cost for this treatment may not justify using the one step process in real applications where safe disposal is the prime objective.

\section{Conclusions}

As(III) is oxidized to $\mathrm{As}(\mathrm{V})$ by the $\gamma-\mathrm{MnO}_{2}$ with almost equal molar stoichiometric release of $\mathrm{Mn}$ (II) into solution. The rate of the oxidation is characterised by an initial fast kinetics followed by a first order rate reaction. No significant variation in the oxidation rate occurs in the $\mathrm{pH}$ range $4-8$, except for a decreased trend at $\mathrm{pH}$ above 6, is observed. The adsorption of $\mathrm{As}(\mathrm{V})$ with the $\gamma-\mathrm{MnO}_{2}$ is favored in low $\mathrm{pH} 4$ and decreases rapidly where the $\mathrm{pH}$ rises to 8 . The adsorption capacity of $\mathrm{MnO}_{2}(90 \%$ passing $10 \mu \mathrm{m})$ is $1.5 \mathrm{mg}(\mathrm{As}(\mathrm{V}) / \mathrm{g}$ at $\mathrm{pH} 7$. The $\mathrm{MnO}_{2}$ is more efficient when used as an oxidant in the two step process than in the one step process. All the soluble $\mathrm{Mn}$ (II) ions are removed in the solution in both the processes.

\section{Acknowledgment}

The authors are thankful to DEST, Australia for financial support under INDO-AUS Strategic Research Fund Scheme.

\section{References}

[1] G. H. Khoe, M. T. Emett, M. Zaw and P. Prasad, "Arsenic Removal from Tubewell Water in Bangladesh, Report," Australian Nuclear Science \& Technology Organisation CRC for Waste Management \& Pollution Control ANSTO/C585, CRC/1956R, August 1999.

[2] W. Driehaus and M. Jekel, "Oxidation Process for Trivalent Arsenic," DVGW-Schriftenr., Wasser, Vol. 82, 1993, pp. 55-69.

[3] T. Phommavong, T. Viraraghavan and K. S. Subramanian,
"Removal of Arsenic with $\mathrm{KMnO}_{4}$. Oxidation and Manganese Greensand Filtration," Proceedings of the Annual Conference on West Canadian Water Wastewater Association, 48th, 1996.

[4] Y. Li, M. Xi, F. L. Kong and C. Y. Yu, "Experimental Study on the Removal of Arsenic in Waste Water from Semiconductor Manufacturing," Journal of Water Resource and Protection, Vol. 1, 2009, pp. 48-51.

[5] T. Nishimura and Y. Umetsu, "Removal of As(III), Arse$\operatorname{nic}(\mathrm{V})$ with Manganese from Aqueous Solution by Ozonation," Impurity Control and Disposal in Hydrometallurgical Processes, Toronto, Ontario, Canada, 21-24 August 1994, pp. 91-100.

[6] M. Pettine and F. J. Millero, "Effect of Metals on the Oxidation of As(III) with $\mathrm{H}_{2} \mathrm{O}_{2}$," Marine Chemistry, Vol. 70, No. 1-3, 2000, pp. 223-234. doi:10.1016/S0304-4203(00)00028-1

[7] T. Chen, S. J. Kang, K. P. Olmstead, M. D. Rathsack and J. R. Porter, "Removal of Arsenic from BTEX-Contaminated Groundwater," Water Environment Federation Technical Conference 1996 (WEFTEC'96), 69th Annual Conference \& Exposition, 1996.

[8] E. Nieminski and D. Evans, "Pilot Testing of Trace Metals Removal with Ozone at Snowbird Ski Resort," Ozone: Science \& Engineering, Vol. 17, 1995, pp. 297-309.

[9] Gaid, I. Raguenes and P. Ravarini, "Arsenic Removal at Baudricourt (Vosges, France) Drinkable Water Plant," Industry Water Pollution, Vol. 205, 1997, pp. 54-58.

[10] S. P. Pande, L. S. Deshpande, P. M. Patni and S. L. Lutade, "Arsenic Removal Studies in Some Groundwaters of West Bengal, India," Journal of Environmental Science and Health, Part A: Toxic / Hazardous Substances and Environmental Engineering, Vol. A32, No. 7, 1997, pp. 1981-1987.

[11] R. K. Sinha, A. M. Bandyopadhyaya, B. Roy, G. Poddar, I. Chakravarty, A. Majumdar and K. J. Nath, "Use of Some Iron Salts on Total Removal of Arsenic from Arsenical Tubewell Water of West Bengal," Journal of the Institution of Chemists, Vol. 65, No. 1, 1993, pp. 30-31.

[12] K. Sano and S. Hosudo, "Removal of Arsenic from Water," Jpn. Kokai Tokkyo Koho., Kotobuki Kakoki Kk, Japan. 1995, p. 5.

[13] H. Naito, "Apparatus and Method for Removing Tace Arsenic from Groundwater or Pond Water," Jpn. Kokai Tokkyo Koho, NBL K. K., Japan, 1997, 6 Pages.

[14] W. Zhang, P. Singh and D. M. Muir, "Kinetics of Oxidation of $\mathrm{As}(\mathrm{III})$ with $\mathrm{SO}_{2} / \mathrm{O}_{2}$ and UV Light," In: C. A. Young, Ed., Proceedings of Minor Elements 2000: Processing and environmental aspects of $\mathrm{As}, \mathrm{Sb}, \mathrm{Se}, \mathrm{Te}$, and Bi, SME, Littleton CO, 2000, pp. 333-343.

[15] T. Nishimura, Q. Wang and Y. Umetsu, "Removal of Arsenic from Process Liquors by Oxidation of Iron(II), Arsenic(III) and Sulfur(IV) with Oxygen," In: J. E. Dutrizac and G. B. Harris, Eds., Iron Control and Disposal, CIM, Montreal Quebec, 1996, pp. 535-548.

[16] J. Bednar, J. F. Ranville, T. R. Wildeman, J. R. Garbarino, P. J. Lamothe and K. S. Smith, "Remediation Approaches 
Using Photooxidation of Inorganic and Organic Arsenic Species," ACS National Meeting, American Chemical Society, Division Environmental Chemistry, Vol. 41, 2001, pp. 253-256.

[17] M. T. Emett and G. H. Khoe, "Photochemical Oxidation of Arsenic by Oxygen and Iron in Acidic Solutions," Water Research, Vol. 35, No. 3, 2001, pp. 649-656. doi:10.1016/S0043-1354(00)00294-3

[18] G. H. Khoe, M. Zaw, P. S. Prasad and M. T. Emett, "Photo-Assisted Oxidation of Inorganic Species in Aqueous Solutions," PCT Int. Appl. Wo, CRC for Waste Management \& Pollution Control Limited, Australia; Australian Nuclear Science and Technology Organisation, 1999, $30 \mathrm{p}$.

[19] S. J. Hug, L. Canonica, M. Wegelin, D. Gechter and U. von Gunten, "Solar Oxidation and Removal of Arsenic at Circumneutral pH in Iron Containing Waters," Environmental Science \& Technology, Vol. 35, No. 10, 2001, pp. 2114-2121. doi:10.1021/es001551s

[20] L. Carlson and U. Schwertmann, "Iron and Manganese Oxides in Finnish Ground Water Treatment Plants," Water Research, Vol. 21, No. 2, 1987, pp. 165-170. doi:10.1016/0043-1354(87)90045-5

[21] M. Ogawa, M. Kato, T. Okuyama and T. Saito, "Removal of As from Water by Manganese Dioxide," Shigen Kankyo Taisaku, Vol. 37, 2001, pp. 1459-1468.

[22] T. Takamatsu, M. Kawashima and M. Koyama, "The Role of Manganese(2+)-Rich Hydrous Manganese Oxide in the Accumulation of Arsenic in Lake Sediments," Water Research, Vol. 19, No. 8, 1985, pp. 1029-1032. doi:10.1016/0043-1354(85)90372-0

[23] D. W. Oscarson, P. M. Huang, C. Defosse and A. Herbillon, "Oxidative Power of Manganese(IV) and Iron(III) Oxides with Respect to Arsenic(III) in Terrestrial and Aquatic Environments," Nature, Vol. 291, No. 5810, 1981, pp. 50-51.

[24] B. A. Manning, S. E. Fendorf and D. L. Suarez, "Arsenic(III) Complexation and Oxidation Reactions on Environmental Surfaces," Environmental Science \& Technology, Vol. 36, No. 5, 2002, pp. 976-981.

[25] B. A. Manning, S. E. Fendorf and D. L. Suarez, "Arsenic(III) Complexation and Oxidation Reactions on Soil," ACS Symposium Series, Vol. 835, 2003, pp. 55-69

[26] B. A. Manning, E. Fendorf Scott, B. Bostick, and L. Suarez Donald, "Arsenic(III) Oxidation and Arsenic(V) Adsorption Reactions on Synthetic Birnessite," Environmental Science \& Technology, Vol. 36, 2002, pp. 976981.

[27] D. W. Oscarson, P. M. Huang, W. K. Liaw and U. T. Hammer, "Kinetics of Oxidation of Arsenite by Various Manganese Dioxides," Soil Science Society of America Journal, Vol. 47, 1983, pp. 644-648. doi:10.2136/sssaj 1983.03615995004700040007x

[28] H. Chen and S. Fang, "Study on Oxidation of As(III) to $\mathrm{As}(\mathrm{V})$ by $\mathrm{MnO}_{2}$ in wastewater," Gaoxiao Huaxue Gong- cheng Xuebao, Vol. 14, 2000, pp. 48-52.

[29] M. J. Scott and J. J. Morgan, "Reactions at Oxide Surfaces. 1. Oxidation of As(III) by Synthetic Birnessite," Environmental Science and Technology, Vol. 29, 1995, pp. 1898-1905. doi:10.1021/es00008a006

[30] V. Q. Chiu and J. G. Hering, "Oxidation State of Arsenic on Manganite (.Gamma.-MnOOH) Surfaces," 217th ACS National Meeting, Anaheim, 21-25 March 1999.

[31] H. W. Nesbitt, G. W. Canning and G. M. Bancroft, "XPS Study of Reductive Dissolution of 7 A-Birnessite by $\mathrm{H}_{3} \mathrm{AsO}_{3}$, with Constraints on Reaction Mechanism," Geochimica et Cosmochimica Acta, Vol. 62, No. 12, 1998, pp. 2097-2110.

[32] S. Ouvrard, M.-O. Simonnot and M. Sardin, "Reactive Behavior of Natural Manganese Oxides toward the Adsorption of Phosphate and Arsenate," Industrial \& Engineering Chemistry Research, Vol. 41, No. 11, 2002, pp. 2785-2791.

[33] S. Chakravarty, V. Dureja, G. Bhattacharyya, S. Maity and S. Bhattacharjee, "Removal of Arsenic from Groundwater Using Low Cost Ferruginous Manganese Ore," Water Research, Vol. 36, No. 3, 2002, pp. 625-632. doi:10.1016/S0043-1354(01)00234-2

[34] S. Bajpai and M. Chaudhuri, "Removal of Arsenic from Ground Water by Manganese Dioxide-Coated Sand," Journal of Environmental Engineering, Vol. 125, No. 8, 1999, pp. 782-784.

[35] T. Kasai, H. Koyanaka, J. Aizawa and Y. Fujimoto, "Removal of Arsenic Ion from Aqueous Solution with Manganese Oxide," Nippon Bunri Daigaku Kiyo, Vol. 28, No. 2, 2000, pp. 81-86.

[36] T. Kasai and H. Koyanaka, "Removal of Arsenic Ion with Manganese Oxide Compounds," Transactions of the Materials Research Society of Japan, Vol. 27, 2002, pp. $463-$ 466.

[37] J. J. Wen and L. H. Odell, "Case Studies on Concurrent Arsenic Removal in Pyrolusite Iron and Manganese Treatment," Proceedings-Water Quality Technology Conference, 1999, pp. TU11.5.1-TU11.5.14.

[38] A. Vogel, "Text Book of Quantitative Inorganic Analysis," 3rd Edition, Longman, London, 1961.

[39] S. B. Kanungo and D. M. Mahapatra, "Interfacial Properties of Some Hydrous Manganese Dioxides in 1-1 Electrolyte Solution," Journal of Colloid and Interface Science, Vol. 131, 1989, pp. 103-111. doi:10.1016/0021-9797(89)90150-1

[40] S. Ardizzone and S. Trasatti, "Interfacial Properties of Oxides with Technological Impact in Electrochemistry," Advances in Colloid and Interface Science, Vol. 64, 1996, pp. 173-251. doi:10.1016/0001-8686(95)00286-3

[41] P. Thanabalasingam and W. F. Pickering, "Effect of $\mathrm{pH}$ on Interaction between Arsenic(III) or Arsenic(V) and Manganese(IV) Oxide," Water, Air, and Soil Pollution, Vol. 29, No. 2, 1986, pp. 205-16. doi:10.1007/BF00208409 